\title{
Bolsa familia: inequality and education in Brazil
}

\section{Familia bolsa: desigualdad y educación en Brasil}

Andrés Chávez

Universidad Internacional del Ecuador

Autor para correspondencia: anchavezer@internacional.edu.ec

Fecha de recepción: 20 de Enero de 2016 - Fecha de aceptación: 17 de Marzo de 2016

\section{Resumen}

Este estudio se enfoca en las metas establecidas en el programa Education For All Phase II y en el trabajo que el Banco Mundial ha realizado para poder alcanzar las metas para Haiti. Esta investigación analizara Calidad en la Educación, El fortalecimiento Institucional y de Gobierno, y las Nuevas Tendencias en Educación Internacional y Desarrollo.

Palabras claves: banco mundial; education for all; haití; reformas educativas

\begin{abstract}
This study focuses on the established goals of Phase II of Education for All and the work that World Bank has done in order to reach these goals in Haiti. This research will analyze Quality of Education, Institutional Strengthening and Governance, and New Trends in International Development Education.
\end{abstract}

Key words: world bank; education for all; haiti; education reforms 


\section{Introduction}

Despite having the fifth largest economy in the world, a significant percentage of the population of Brazil is considered to be poor or indigent. In 2004, $41.4 \%$ of the population fell into these classes and had access to less than half the minimum wage (Reiter, 2009). This is indicative of the high rate of inequality experienced by the people in the country. In Brazil, the most prosperous quintile of the population earns almost two-thirds of the country's personal income, while the poorest quintile earns a mere 2.3 percent; this makes Brazil the country with the seventh most inequitable distribution of income in the world (Hall, 2008).

These financial inequalities correlate to inequalities in education; for example, only

$49.5 \%$ of the country's population has completed secondary education (Human Development Report, 2013). Inequalities such as this are important to note because, especially in South America, "disparities in educational attainment continue to be sharp at those levels that currently matter most to employers for access to the better-paid jobs" (Reimers, 2000, p. 433). Such disparities need to be addressed in order to break the cycle of poverty in the poorest sectors of

Brazil. One program that has attempted to lessen inequalities in the country is the Bolsa Familia conditional transfer program, which started in 2003. Over 13 million people have enrolled in this program, which provides financial aid to Brazilian families in poverty under the condition that they send their children to school. The purpose of this paper is to describe the characteristics of the program, evaluate its achievements in order to understand its effects with regard to education inequality, examine the criticism that the program has received, and finally explore some ways in which the program can be improved.

\section{Description of Bolsa Familia}

Conditional cash transfer (CCT) programs, such as Bolsa Familia, have become widely employed by governments in Latin America because they are easy to target at families that meet certain geographical and household level criteria, and it is more cost-effective to provide cash directly to families than to use a benefit system such as food stamps or vouchers (Hall, 2006).

Additionally, these programs focus on the intersecting components of health, education, and nutrition, which all work together to strengthen human capital (Hall, 2008). CCT programs are also more flexible than other social welfare programs, and have been found to be "efficient and transparent in their implementations, focused on the future with a clear set of goals (Rawlings \&Rubio, 2005, p. 6). Bolsa Familia is now the largest CCT program in the world, and it is divided into four smaller programs, which are educational stipends to boost school attendance, maternal nutrition, food supplements, and a domestic gas subsidy (Hall, 2006). As shown in Figure 1, the number of families served by the program nearly doubled between the years of 2004 and 2010, and the amount of money (shown in Brazilian Real) donated to these families more than quadrupled over the same time period. 


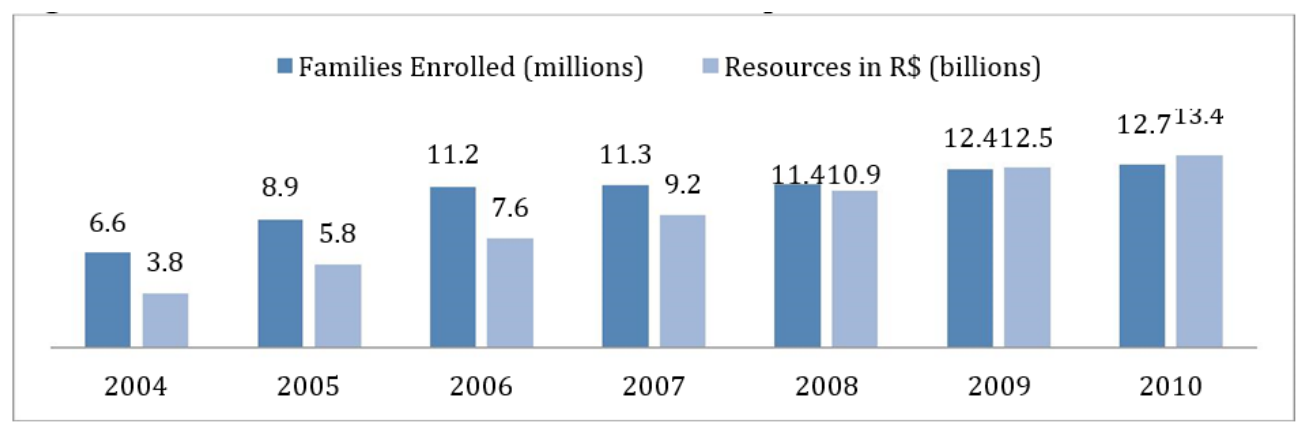

Figure 1 Bolsa Familia Enrollment and Resources Spent Source: MDS, 2013

Bolsa Familia works by giving conditional cash payments to families that declare 1 themselves to be either 'very poor' with a monthly income equal to or less than R $\$ 60^{1}$ (US\$ 36) or 'poor' with a monthly income between R $\$ 60.01$ and R 120 (US\$ 73) a month. Families that are 'very poor' receive a monthly payment of R\$ 58 (U\$ 35) regardless of their household composition. These funds act as a safety net to help those with the most extreme needs.

Additionally, families are eligible to receive monthly payments per child for up to five children through seventeen years of age, with payments being conditional upon "proof of regular school attendance, children's vaccination, visits to health clinics and other activities such as participation in nutrition and vocational training courses" (Hall, 2008, p. 806). These families also receive monthly payments for food, gas, and other necessities, and additional money is given to families with a pregnant or lactating woman who is receiving the proper health care. These payments are made through a bank card and are almost always given to the head female of 1 Figures are based on an exchange rate of US\$1 $=\mathrm{R} \$ 1.65$ at the time of writing in May 2008.the family, owing to the research that has shown that "women tend to use additional income to raise their families' wellbeing” (Glewwe \& Kassouf, 2012, p. 508).

The monitoring of families' compliance with specific conditions is the responsibility of the Ministries of Education, Health, and Social Development. These ministries are to identify families that are failing to comply and make plans to support them through the obstacles that are impeding their cooperation with the program (MDS, 2013). The program has become more closely supervised in recent years; in the beginning, it was rare for a family to lose benefits for not complying with the conditions. In February 2010, approximately 709,900 families lost their benefits for not updating their children's enrollment information (Fried, 2012). The oversight of this program is important because it is attempting to address the multidimensional aspect of poverty by integrating different facets of life, such as education and health. If families do not comply with the conditions of the program, they will not benefit from increased levels of education or improved health and nutrition, and the program will be unable to help them in the way that is intended.

\section{Effects of Bolsa Familia}

Since the start of Bolsa Familia, there has been a 3.6 percent increase in school attendance among the families participating in the program, as well as an increase of 2.6 percent

\footnotetext{
${ }^{1}$ Figures are based on an exchange rate of US\$ $1=R \$ 1.65$ at the time of writing in May 2008.
} 
in labor market participation. There have been increased enrollment rates in both early childhood and primary education for children between the ages of three and six, though these rates are still below the OECD averages (OECD, 2012). Enrollment in early childhood education is a concern because in 2008, only $50 \%$ of children between the ages of three and five were in school. This is an issue that merits some attention due to the fact that "pre-primary education has proven to have a positive impact on future students' school career" (UNESCO, 2011, p. 1).

In 2010, 92\% of six-year olds in Brazil were enrolled in primary education, which represents a significant improvement over the $83 \%$ of children that age that were enrolled in school in 2005 (OECD, 2012). The gross enrollment rate for primary education in Brazil was $95 \%$ in 2008, with a completion rate of nearly 95\%; however, the country has one of the highest repetition rates in Latin America, with $24.5 \%$ of students repeating the first grade of primary education (UNESCO, 2011). This high rate of repetition is a cause for concern because it indicates poor performance in school and may lead to higher dropout rates in the future. Therefore, notwithstanding the improvements made to enrollment rates, more changes need to be made to target the students who are still not enrolled in school in order to achieve the nation's goal of universal primary education, and the education system should be adjusted to help students be more successful and thereby decrease repetition rates.

Enrollment in secondary schools has increased since the implementation of Bolsa Familia as well. In 2008, $81 \%$ of high school age children were enrolled in school, with a completion rate of 55\% (UNESCO, 2011). This demonstrates improvement over previous years in the country, as well as higher averages than other countries in the region. School level estimates indicate that Bolsa Familia has contributed to reduce dropout rates and helped to equalize student enrollment in terms of race (Glewwe \& Kassouf, 2012).

There has also been a decrease in the number of people living in absolute poverty; from 2003, when the program started, to 2005, there was a decrease in absolute poverty of over 19 percent (Hall, 2008). As shown in Figure 2, the poverty gap began a sharp decline following the institution of Bolsa Familia. The unconditional monthly payment given to families in extreme poverty has helped to boost many of Brazil's poorest people to a higher standard of living. This decrease in inequality since 2003 has been accompanied by a decrease in crime rates in Brazil as well (Chioda \& Soares, 2012). It is likely that fewer people feel the need to break the law in order to provide for their families now that a small amount of funding is readily available to them.

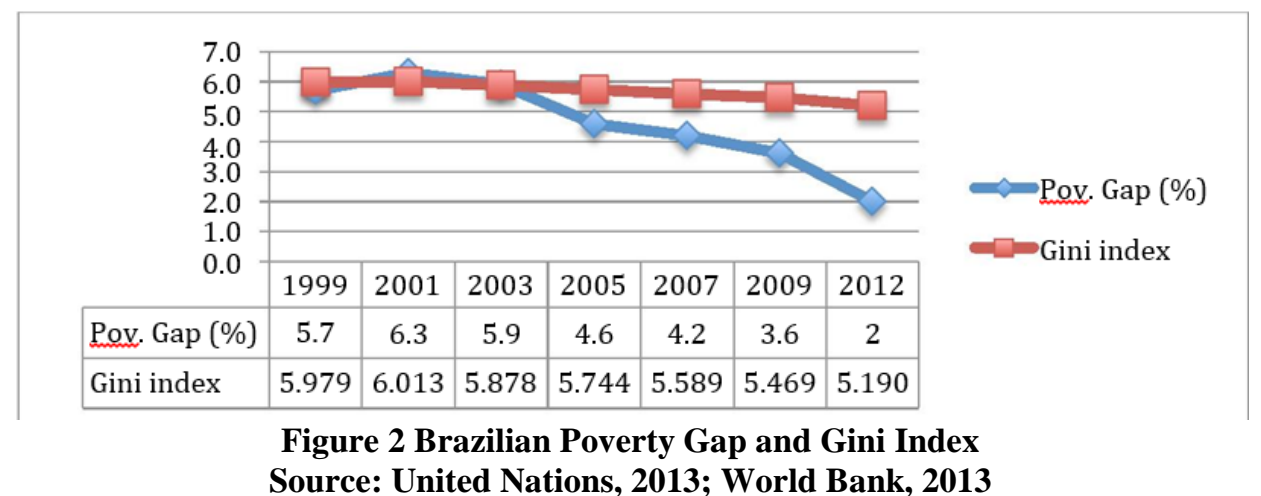

Source: United Nations, 2013; World Bank, 2013 


\section{Criticism of Bolsa Familia}

Despite the positive effects that Bolsa Familia has had on school enrollment and more equitable distribution of income, the program has been criticized for failing to address issues of quality in education. The current program design does not make any provisions that address education quality, and the concern is that children who are now attending school because of Bolsa Familia will not benefit as much from the education they receive as is anticipated by the government. Some researchers propose that a portion of the billions of dollars that are invested in Bolsa Familia "should be allocated instead to improve the quality of the Brazilian public educational system, making schools more capable of dealing with children from deprived families" (Haddad, 2008). Education truly helps children when it is relevant to their circumstances and prepares them to take advantage of the opportunities that await them upon graduation. If the schools in Brazil are not equipped to do this, the students will not become empowered to change and improve the future of their country, no matter how much money is provided for increasing access to these schools. Critics point out that cash transfers such as Bolsa Familia are limited in their ability to alleviate poverty because "they are channeled into basic consumption and do not boost income-earning capacity or household assets" (Hall, 2008, p.812).

One evidence of the limitations of the program is that in spite of decreases to the poverty gap, incidences of poverty are still significantly higher in certain regions of Brazil than others. There has been an overall decrease in poverty across all regions of the country, which is a positive result that can at least partially be attributed to Bolsa Familia, but the fact that families in one region are much more likely to live in poverty than the families of another represents a persisting inequality. Figures 3 and 4 show the numbers of people living in extreme poverty and poverty, respectively. As evidenced by the figures, there are significantly more poor people in the Northeast and Southeast regions of Brazil than in the rest of the country. It will require more than giving families monetary handouts to equalize the opportunities of the children living in the poorest regions of Brazil. Just as poverty affects the level of education that students are able to achieve, the quality of education that a student is able to access affects his or her future likelihood of living in poverty. In order to truly break the cycle of poverty, Bolsa Familia needs to focus on providing a high quality education to children in all regions of the country. This education, in conjunction with the improved standards of health and nutrition provided by the program, will empower students to rise above difficult circumstances and make a better life for themselves and their posterity.

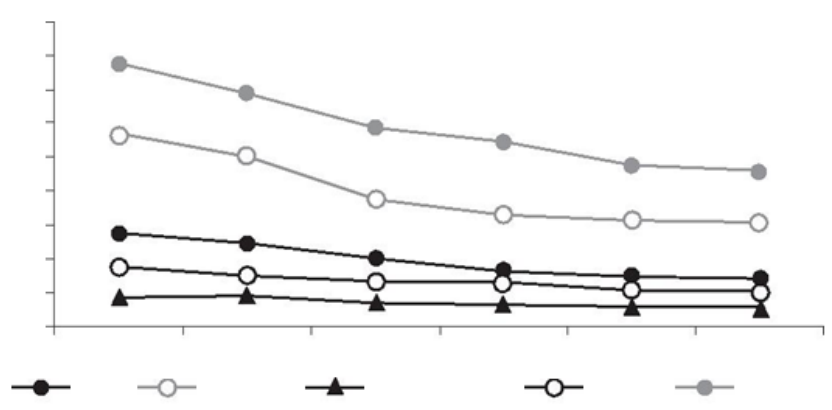

Figure 3 Number of people living in extreme poverty by region (thousands) Source: Araujo a, Alves \& Besarriac, 2013 


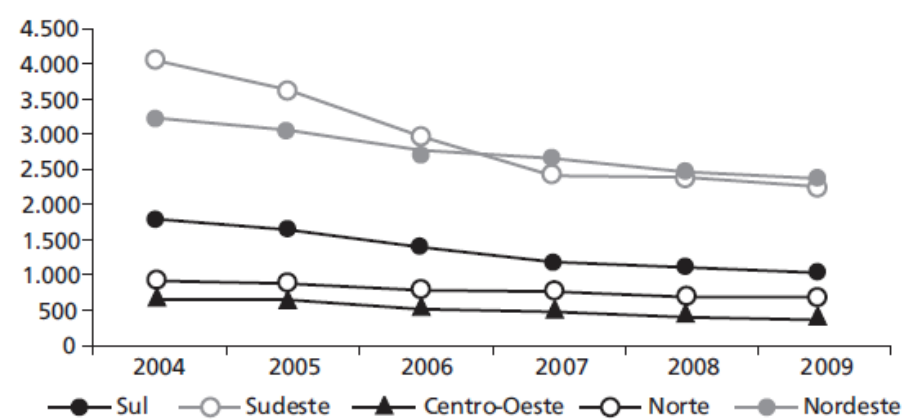

Figure 4 Number of people living in poverty by region (thousands)

\section{Recommendations for Improving Bolsa Familia}

One country in Latin America that has been successful in equalizing students through education is Cuba. Cuban schools do not reproduce inequalities as they are seen to do in Brazil for a variety of reasons, among them the fact that children from all socioeconomic backgrounds have access to the same quality of schools and the same compulsion to attend. A valid question, then, is how a country like Brazil "can approach the degree of social safety, moral imperative, and educational quality control achieved by Cuba, and do so in the context of political democracy" (Carnoy, 2007, p. 43). One important aspect of this is ensuring that students in all regions have access to favorable educational circumstances, such as properly trained teachers, manageable student-class ratios, and adequate infrastructure. These components of education are currently not part of the scope of Bolsa Familia, but they should be considered if education is to be used as an equalizing and empowering tool for Brazilian children.

It will also be important to focus particularly on the most marginalized people in society. In Brazil, the poorest people live in shantytown outskirts of bigger cities that are called favelas. These people are exploited by the society that surrounds them, and it is nearly impossible for them to move upward socially. A study done in the favelas of Brazil revealed that, among these people, having a job was considered to be the most important thing; more important than education, health, housing, and security (Perlman, 2010). With this perspective in mind, it is understandable that these people may not see the benefit of complying with the conditions of Bolsa Familia. The program is not geared towards helping people get jobs, which is their top priority, and if the education provided in Brazil is insufficient to prepare students for obtaining better jobs, they will have little motivation to participate in the program. In order to achieve universal education and help these marginalized people to experience social mobility, Bolsa Familia will need to be adapted to the unique needs and opportunities of the people who most need help. As Paulo Freire said, "Many political and educational plans have failed because their authors designed them according to their own personal views of reality, never once taking into account to whom their program was ostensibly directed" (Freire, 2000, p. 153). In addressing the problem of inequality, the reality that matters most is that of the people who are being inequitably treated. That reality must be taken into consideration in order for programs like Bolsa Familia to have their intended effect and produce a real change in Brazilian society. 


\section{Conclusion}

Bolsa Familia has had positive effects in Brazil. Most notably, school enrollment has increased across preprimary, primary, and secondary levels, and the number of people living in poverty and absolute poverty has decreased. However, there are still considerable problems with inequality in Brazil that the program has not been able to resolve. One main oversight of Bolsa Familia is the lack of attention given to quality of education, which is crucial to increasing social mobility. Another potential problem is the lack of relevancy that the most marginalized people of Brazil perceive in the program. In order to have a greater effect, Bolsa Familia needs to address the roots of inequality in Brazil rather than merely treat the symptoms. All children in Brazil must be granted access to high quality education that will empower and enable them to create the social changes in their communities that will lead to greater equity and prosperity for the future generations.

\section{Bibliography}

Araujo a, J. M., Alves, J., \& Besarriac, C. N. (2013). The Impact of Social Spending Over Indicators of Inequality and Poverty in the Brazilian States in the Period 2004-2009.

Carnoy, M., Gove, A. K., \& Marshall, J. H. (2007). Cuba’s Academic Advantage: Why students in Cuba do better in school. Stanford, California: Stanford University Press.

Chioda, L., De Mello, J. M., \& Soares, R. R. (2012). Spillovers from Conditional Cash Transfer Programs: Bolsa Familia and Crime in Urban Brazil. Discussion Paper Series, 6371, 1-20.

Freire, P. (2000). Pedagogy of the oppressed (30th anniversary Ed.). New York: Continuum.Fried,

B. J. (2012). Distributive Politics and Conditional Cash Transfers: The Case of Brazil's Bolsa Familia. World Development, 40(5), 1042-1053.

Glewwe, P., \& Kassouf, A. L. (2012). The Impact of the Bolsa Escola/Familia Conditional CashTransfer Program on Enrollment, Dropout Rates and Grade Promotion in Brazil.Journal of Development Economics, 97(2), 505-517.

Haddad, M. (2008). Bolsa Familia and the Needy: Is Allocation Contributing To Equity InBrazil? Journal of International Development, 20, 654-669.

Hall, A. (2006). From Fome Zero to Bolsa Familia: Social Policies and Poverty AlleviationUnder Lula. Journal of Latin American Studies, 38(4), 689-709.

Hall, A. (2008). Brazil's Bolsa Familia: A Double-Edged Sword? Development and Change,39(5), 799-822.

Human Development Report. (2013). the Rise of the South: Human Progress in a DiverseWorld. Retrieved November 8, 2013, from http://hdrstats.undp.org/images/explanations/BRA.pdf 
(MDS) Ministerio do Desenvolvimiento Social e Combate à Fome. (2013). Bolsa Familia. Ministerio do Desenvolvimiento Social e Combate à Fome. Retrieved November 23, 2013, from http://www.mds.gov.br/bolsafamilia

OECD. (2012). Education at Glance: OECD Indication 2012. Brazil. Retrieved November 8, 2013, from http://www.oecd.org/education/EAG2012\%20-\%20Country\%20note\%20$\%$ 20Brazil.pdf

Perlman, J. (2010). Favela: Four Decades of Living on the Edge in Rio de Janeiro. New York:Oxford University Press

Peterson, P. E., \& Campbell, D. E. (2001). Charters, vouchers, and public education.Washington, D.C.: Brookings Institution Press.

Rawlings, L., \& Rubio, G. (2005). Evaluating the impact of conditional cash transfer programs: lessons from Latin America. Washington, D.C.: World Bank, Latin American and the

Caribbean Region, Human Development Sector Unit.Reimers, F. (2000). Unequal schools, unequal chances: the challenges to equal opportunity in the Americas. Cambridge, Mass.: Harvard University Press.

Reiter, B. (2009). Inequality and School Reform in Bahia, Brazil. International Review of Education, 55(4), 345-365.

UNESCO. (2011). State of Education in Latin America and the Caribbean: Ensuring Quality Education for All. Washington D.C.: UNESCO.

United Nations. (2013). UNdata - A World of Information. Brazil Poverty gap ratio. $\begin{array}{lll}\text { RetrievedNovember 29, 2013, } & \text { 29, }\end{array}$ fromhttp://data.un.org/Data.aspx?d=MDG\&f=seriesRowID\%3A584

WorldBank. (2013). GINI index. Data. Retrieved December 2, 2013, from http://data.worldbank.org/indicator/SI.PO 